\title{
Peran Kampanye Tematik Iklan A Mild Dalam Membentuk Brand Image Rokok A Mild
}

\author{
Nur Aini Shofiya Asy'ari \\ Prodi Ilmu Komunikasi, Fakultas Humaniora, Universitas Darussalam \\ Gontor. \\ Raya Siman KM.5 Ponorogo 63471. Indonesia. \\ Email : nurainishofia@unida.gontor.ac.id
}

\begin{abstract}
ABSTRAK
Iklan dalam paradigma wacana merupakan model komunikasi yang mengkomunikasikan citra secara maksimum dalam waktu yang minimum dan diharapkan dapat mencapai sasaran dan memberikan keuntungan kepada produsen. Karena pengaruhnya yang sangat besar maka khusus untuk iklan rokok dibatasi ruang geraknya oleh undang-undang No.24 tahun 1997 tentang Penyiaran, Tata Krama serta Tata Cara Periklanan Bab II Poin C butir 7. Hal ini menjadi stimulus bagi produsen iklan rokok untuk lebih kreatif dalam menyampaikan pesan. Iklan rokok A Mild memilih untuk memproduksi iklan dengan mengangkat fenomena-fenomena yang sedang ramai dibicarakan. Tujuan penelitian ini adalah untuk mengetahui bagaimana hubungan antara thematic campaign iklan A Mild (How Low You Can Go, Others can only follow, Bukan Basa-basi, Tanya Kenapa dan Go A head). Dengan brand image rokok A Mild. Untuk mengetahui pesan iklan A Mild penelitian ini menggunakan analisis semiotika Roland Barthes. Dari analisis isi pesan iklan diketahui bahwa iklan A Mild merupakan representasi fenomena social yang sedang terjadi di masyarakat. Iklan $A$ Mild menggunakan kampanye tematik dalam pembuatan iklannya disesuaikan dengan fenomena sosial yang sedang terjadi. Thematic campaign How Low You Can Go dan Others can only follow ditandai dengan hadirnya iklan A Mild dengan kalimat-kalimat yang ditujukan pada para kompetitor produsen rokok low tar low nicotin (LTLN) yang mengikuti langkah A Mild, Thematic campaign Bukan Basa Basi dan Tanya Kenapa merupakan tema kampanye iklan yang bertujuan mengkritisi fenomena sosial yang sedang terjadi, Sementara thematic campaign Go Ahead adalah iklan dengan pesan pada khalayaknya untuk terus berani melangkah ke depan. Thematic campaign iklan A Mild secara keseluruhan ingin membentuk citra konsumen yang cerdas, trend setter, kritis dan berani. Dengan bahasa lain bahwa A Mild lewat iklannya ingin menyampaikan bahwa jika konsumen rokok merasa dirinya cerdas, trendsetter, up to date,berani, kritis maka konsumen tersebut pasti akan memilih A Mild sebagai rokok yang dikonsumsinya.
\end{abstract}

Kata Kunci : Iklan A Mild, Brand Image, Thematic Campaign 


\section{PENDAHULUAN}

Peran media massa di dalam masyarakat menjadi sangat penting. Denis Mc. Quail (2000) menyatakan bahwa media telah menjadi sumber yang dominan untuk memperoleh gambaran dan citra realitas sosial, baik bagi idividu, kelompok, maupun masyarakat secara umum. Salah satu media massa yang perkembangannya pesat adalah Televisi. Bahkan di era new media televisi masih mampu bertahan karena karakter-karakter yang dimilikinya. Televisi sebagai media audio visual dapat menampilkan informasi secara lebih lengkap jika dibandingkan dengan media cetak yang hanya bisa menampilkan gambar tidak bergerak ; atau radio yang hanya memperdengarkan suara saja. Hal ini menjadi dasar pemikiran bahwa televisi merupakan media yang paling efektif untuk transformasi pesan maupun gagasan.

Iklan adalah bagian yang tidak terpisahkan dari kehidupan masyarakat. Bagaimana tidak, mengingat intensitasnya yang tiap hari dalam 24 jam membombardir masyarakat dengan pesan dan ideologi yang hendak disampaikan. Setiap harinya iklan menjadi sangat lekat dengan kehidupan masyarakat, di jalan, radio, koran, majalah, televisi maupun internet.

Mengingat pengaruhnya yang besar dan dapat menciptakan pola pikir baru dalam masyarakat, beberapa iklan dibatasi ruang geraknya oleh undang-undang. Contohnya UU. No.24 Tahun
1997 tentang Penyiaran, Tata Krama scrta Tata Cara Pcriklanan di Indonesia yang membatasi kegiatan merokok pada iklan rokok. Tata krama periklanan yang disebutkan dalam Bab II Poin $\mathrm{C}$ butir ke-7 adalah sebagai berikut :

" Pertama, iklan tidak boleh mempengaruhi atau merangsang orang untuk mulai merokok; kedua, iklan tidak boleh menyarankan bahwa tidak merokok merupakan hal yang tidak wajar; ketiga, iklan tidak boleh menggambarkan orang merokok dalam kegiatankegiatan yang membahayakan; keempat, iklan rokok tidak boleh menampilkan atau ditujukan untuk anak-anak dibawah usia 16 tahun dan atau wanita hamil; kelima, iklan rokok tidak boleh dimuat pada media periklanan yang khalayak sasaran utamanya adalah anak-anak dibawah usia 16 tahun"

Hal ini menyebabkan produsen iklan rokok ditantang untuk lebih kreatif dalam mengemas pesannya. Maka dalam perkembangannya pesan iklan rokok yang ada menjadi disconnectivity antara visualisasi iklan dengan produk yang ingin diiklankan, dalam artian bahwa iklan rokok saat ini tidak menjual produknya namun menjual branding dari produk rokok itu sendiri. 
Jurnal LINIMASA, Volume 1 Nomor 2, Juli 2018, hlm 52 - 67

Iklan-iklan A-Mild merupakan iklan yang dapat memposisikan produknya sebagai produk dengan segmentasi yang cerdas, trendsetter, kritis dan berani yang selalu up todate dalam menanggapi segala persoalan disekitarnya. Sebagai contoh iklan A-Mild versi Kalau Benda Bisa Ngomong dan Kalau Gak Dibersihin, Kutu Busuknya Gak Akan Pergi yang mencoba mengkritisi fenomena pemilu 2004 dimana saat itu masyarakat Indonesia mulai bersikap apatis dikarenakan kepercayaan terhadap pelaku-pelaku politik tanah air yang mulai menipis. Atau iklan A-Mild versi Banjir Bandang yang menggambarkan kondisi bangsa yang tidak pernah bisa lepas dari banjir saat penghujan tiba.

Iklan A-Mild sejak kemunculannya menarik perhatian dan membuat banyak kalangan membicarakannya sebagai iklan kreatif yang dapat mengangkat tema-tema sosial maupun politik dengan kemasan yang menarik. Beberapa iklannya dibicarakan dalam forum internet yang menandakan bahwa iklan A-Mild adalah sebuah fenomena dalam dunia komunikasi yang isi pesannya perlu diintepretasikan melalui studi-studi yang didasarkan pada wacana keilmuan yang ada. Maka, A-Mild menarik untuk penulis diintepretrasikan maknanya dalam bentuk tulisan ilmiah dengan judul " Tematic Campaign dan Brand Image Iklan A-Mild. (How Low Can You Go, Others Can Only Follow, Bukan Basa-Basi, Tanya Kenapa \& Go Ahead)"

\section{METODE PENELITIAN}

Penelitian ini merupakan penelitian kualitatif dengan metode analisis isi. Menurut Maleong penelitian kualitatif adalah penelitian yang bermaksud untuk memahami fenomena tentang apa yang ditimbulkan oleh subjek peneltian, misalnya perilaku, persepsi, dan tindakan lain dengan deskripsi dalam bentuk kata dan bahasa, pada suatu konteks khusus alamiah dan dengan berbagai metode ilmiah. Sementara tujuan penelitian yang mengambil judul Tematic Campaign dan Brand Image Iklan A-Mild. (How LowCan You Go, Others Can Only Follow, Bukan Basa-Basi, Tanya Kenapa \& Go Ahead) adalah untuk mengetahui bagaimana hubungan antara thematic campaign dengan brand image iklan A Mild

Jenis sumber data yang digunakan dalam penelitian ini adalah data primer dan data sekunder. Data primer didapatkan dari hasil pengkodean penulis terhadap iklan-iklan A Mild yang dimuat di televisi, billboard, koran maupun situs-situs online. Sedangkan data sekunder penulis ambil dari literatur buku dan situs-situs internet untuk melengkapi data yang telah ada.

\section{TINJAUAN TEORITIS}

\section{Komunikasi Massa}

Komunikasi adalah proses
penyampaian pesan oleh
seseorang kepada orang lain untuk
memberitahu atau mengubah
sikap, pendapat ataur perilaku


Nur Arini Shofiya Asu'ari Prodi ilmu Komunikasi...55

baik secara langsung maupun tidak langsung melalui media (Effendy, 2009). Dalam definisi tersebut tersimpul tujuan yakni memberitahu atau mengubah sikap (attitude), pendapat (opinion) atau perilaku ( behaviour)

Sedangkan menurut Miller :

“ Komunikasi terjadi
ketika suatu sumber
menyampaikan suatu
pesan kepada penerima
dengan niat yang disadari
untuk mempengaruhi
perilaku penerima'
(Mulyana, 2008)

Setiap hari manusia melakukan komunikasi, apakah komunikasi interpersonal, organisasi, ataupun komunikasi massa. Sebuah perusahaan melakukan komunikasi dengan masyarakat melalui iklan, dimana iklan disampaikan ke audience melalui media massa. Kaitan komunikasi dengan iklan sangatlah erat, terlihat dari bagaimana sebuah perusahaan berusaha menyampaikan pesan dengan berbagai macam proses yang salah satunya tertuang dalam iklan.

Komunikasi massa adalah komunikasi dengan menggunakan media massa, baik cetak (surat kabar, majalah) maupun elektronik (radio, televisi) yang dikelola oleh suatu lembaga atau orang yang dilembagakan, yang ditujukan kepada sejumlah orang yang tersebar di banyak tempat, anonim dan heterogen. Pesanpesannya bersifat umum, disampaikan secara cepat dan serentak dan pada media elektronik bersifat selintas (Mulyana, 2006)

Secara umum, media massa yang digunakan dalam komunikasi massa berbeda fungsi dari institusi pengetahuan seperti seni, agama, ilmu pengetahuan, pendidikan dan lain-lain. Media massa memiliki fungsi pengantar segenap macam pemberitahuan dan dengan demikian ia juga memainkan peranan institusiinstitusi tersebut. Karena menyelenggarakan kegiatannya dalam lingkungan publik, media massa dapat dijangkau oleh segenap anggota masyarakat secara bebas, sukarela, umum dan murah. Hubungan antara pengirim dengan penerima dalam komunikasi massa bersifat seimbang dan sama. Dan, media massa menjangkau paling banyak orang dibanding institusi lainnya sehingga dapat mengambil alih peranan sekolah, orang tua, agama dan lain-lain (Mc. Quail , 2011)

Maka, iklan televisi dapat dikategorikan sebagai salah satu bentuk komunikasi massa. Karena, iklan televisi memiliki karakter yang sama seperti komunikasi massa. Iklan televisi dikelola oleh lembaga, ditujukan pada khalayak yang sporadik, anonim dan heterogen dengan pesan-pesan umum yang disampaikan secara cepat, serentak dan selintas.

\section{Iklan Korporat}

Secara mendasar ada tiga tipe iklan televisi; selling commercial, image commercial dan public announcement. Bila selling 
Jurnal LINIMASA, Volume 1 Nomor 2, Juli 2018, hlm 52 - 67

commercial bertujuan menimbulkan keinginan untuk membeli produk yang diiklankan, public service announcement ditayangkan demi kepentingan publik, image commercial bertujuan menciptakan citra yang positif bagi perusahaan, produk atau jasa yang pada akhirnya bisa mendukung penjualan. Image commercial dirancang untuk membantu membentuk suatu identitas bagi pengiklan atau ide tentang produk/ jasa. Iklan jenis ini tidak menonjolkan spesifikasi kualitas produk. Tujuannya adalah memberi batasan konsumen, gaya hidup, tren atau peristiwa terbaru, yang pada akhirnya akan menimbulkan kesadaran dan perasaan positif terhadap perusahaan . Iklan jenis ini seringkali digunakan untuk melawan publikasi buruk yang bisa mengganggu perusahaan

Menurut definisi dari The Publisher Information Burreau (PIB) dalam buku Coorporate Advertising, sebuah iklan dapat digolongkan menjadi iklan korporat apabila memiliki ciri-ciri

- Mendidik, memberi informasi, atau memberi kesan kepada publik sesuai dengan kebijakan, fungsi, fasilitas, tujuan, idealisme dan standar yang dianut sebuah korporat.

- Membangun opini yang positif (favorable) mengenai korporat dengan menekankan pada kompetensi dari manajemen, ketrampilan manufaktur,

perkembangan teknologi dan kontribusi bagi masyarakat atau menampilkan publisitas negatif terhadap korporat yang bersangkutan.

- Membangun kualitas investasi dan meningkatkan struktur financial korporat

- 'Menjual' korporat tersebut sebagai tempat kerja yang baik untuk menjaring lulusan universitas atau orang dengan keterampilan tertentu untuk bekerja di dalamnya (Wibisono, 2008)

Iklan A Mild yang akan diteliti dalam penelitian ini dapat dikategorikan sebagai image commercial atau iklan korporat yang berfungsi mendidik, memberi informasi dan memberi kesan kepada publik sesuai dengan idealisme korporat.

Adapun tujuan dibuatnya iklan-iklan A Mild adalah untuk membentuk citra dan brand equity. Iklan-iklan A Mild pada awalnya dibuat untuk mengkomunikasikan product benefit dari rokok A Mild sebagai pionir varian low tar low nicotin dengan brand essence Bukan Basa Basi sebagai jiwanya. Hal ini dimaksudkan untuk menegaskan segmentasi pasar A Mild yang cerdas, kritis dan trendsetter diantara kompetitornya. Thematic Campaign Tanya Kenapa merupakan sebuah usaha untuk 
mengedukasi masyarakat untuk berpikir kritis atas fenomenafenomena disekitarnya, dan Your Life Your Choice adalah upaya iklan A Mild membentuk konsumen sebagai manusia yang mandiri atas pilihan hidup. Tagline terbaru iklan A Mild Go $A$ Head merupakan upaya merepresentasikan konsumen A Mild yang selalu berani melangkah atas segala keputusan tanpa takut resiko atas keputusan yang diambilnya.

\section{Iklan dan Fenomena Sosial}

Fenomena menurut Kamus Besar Bahasa Indonesia online (http://pusatbahasa.diknas.go.id/k bbi/indekx.php) adalah hal-hal yang dapat disaksikan dengan panca indera dan dapat diterangkan secara ilmiah. Sedangkan sosial didefinisikan sebagai hal-hal yang berkenaan dengan masyarakat. Maka fenomena sosial secara sederhana didefinisikan sebagai hal-hal yang dapat disaksikan dengan panca indera dan dapat diterangkan serta dinilai secara ilmiah yang terjadi dalam lingkungan sosial masyarakat.

Fenomena sosial mencakup segala bidang kehidupan manusia baik sosial, budaya, ekonomi maupun politik. Sebagai contoh, maraknya komunitas gay dan lesbian atau peristiwa-peristiwa politik seperti korupsi, diskriminasi ras, agama dan lainlain. Fenomena sosial dipahami sebagai sebuah realitas sosial karena kejadian yang tampak tersebut adalah kejadian yang telah terjadi dalam kehidupan suatu bangsa.
Menurut Alan Lapides dan Allan Elin dalam 'Designing and Producing The Television Commercials' iklan televisi adalah fenomena sosial yang dibuat berdasarkan realita yang terjadi pada masyarakat suatu bangsa. Iklan televisi merefleksikan budaya sosial serta menyebarkannya kepada masyarakat secara luas. Kemampuannya sebagai bagian dari komunikasi massa memungkinkan iklan televisi dapat mendesain dan memproduksi tayangan dengan singkat yang dapat mengangkat kembali kejadian-kejadian yang sedang popular dalam suatu komunitas masyarakat dan menyebarkan informasi tersebut ke masyarakat yang lain. Iklan televisi bertindak sebagai barometer yang mampu menceritakan kembali peristiwaperistiwa yang berkaitan dengan kondisi suatu bangsa.

Penganut metode semiotic strukturalis meyakini bahwa :

"adalah mustahil mengiklankan sesuatu yang tidak ada referensi sosialnya"

Iklan tanpa refensi sosial akan ditinggalkan audience karena audience tidak mampu memahami sesuatu yang tidak pernah berhubungan dengan kehidupan mereka sehari-hari. Metode intepretasi ini menolak anggapan bahwa iklan mampu menciptakan sebuah dunia yang baru sama sekali. Disini peran iklan direduksi menjadi hanya sebatas sebagai masyarakat, artinya apa yang diiklankan adalah murni berdasarkan pada kebutuhan/ 
Jurnal LINIMASA, Volume 1 Nomor 2, Juli 2018, hlm 52 - 67

keinginan masyarakat.

(http://mardian.wordspress.com)

\section{Semiotika dan Order of Significations}

Secara etimologis, kata semiotika berasal dari bahasa Yunani semeion yang berarti tanda atau seme yang berarti penafsir tanda. Dalam tulisannya, Alex Sobur (2009) mengutip teori Van Zoest yang mengatakan bahwa manusia adalah homo semioticus. Sementara Cassirer dan langer mengatakan bahwa manusia adalah animal symbolism. Dari pernyataan ini dapat ditarik kesimpulan bahwa kehidupan manusia tidak dapat lepas dari tanda.

Tanda-tanda (signs) adalah basis dari seluruh komunikasi (Litlejohn, 1996, dalam Sobur 2009). Manusia dengan perantaraan tanda-tanda dapat melakukan komunikasi dengan sesamanya. Tanda inilah yang menjadi basis semiotika, yang sering didefinisikan sebagai bidang studi yang mempelajari makna atau arti dari suatu tanda atau lambang.

Semiotika memiliki tiga bidang studi utama, yaitu :

- Tanda itu sendiri. Semiotika mempelajari berbagai tanda yang berbeda, cara tanda-tanda yang berbeda itu dalam menyampaikan makna dan cara tanda-tanda itu terkait dengan manusia yang menggunakannya. Tanda adalah kontruksi manusia dan hanya bisa dipahami dalam artian manusia yang menggunakannya.

- Kode atau sistem yang mengorganisasikan tanda. Studi ini mencakup cara berbagai kode dikembangkan untuk memenuhi kebutuhan suatu masyarakat/ budaya atau untuk mengeksploitasi saluran komunikasi yang tersedia untuk

mentransmisikannya.

- Kebudayaan tempat kode dan tanda bekerja. Pada akhirnya ini bergantung pada penggunaan kodekode dan tanda-tanda itu untuk keberadaan dan bentuknya sendiri.(Fiske, 2004)

Tiga bidang studi utama dari semiotika tersebut menjadi acuan dalam penelitian ini, karena sign di dalam teks yang menjadi obyek penelitian menjadi satu atribut utama yang akan dimaknai, sehingga dapat diperoleh kontruksi realitas dari sign tersebut. Kemudian bagaimana tanda-tanda tersebut dikembangkan dan diorganisasikan juga merupakan suatu kajian yang penting dalam analisis teks. Untuk dapat menghasilkan intepretasi yang tepat kita dapat memulai pemahaman mengenai bagaimana sebuah iklan bekerja jika kita dapat melihat kompleksitas kodekode yang memungkinkan rangkaian-rangkaian pesan dinyatakan bersama dalam sebuah teks (Dyer, 1996). 


Dalam menganalisa pesan
iklan korporat dengan
menggunakan fenomena sosial
dalam kontennya, peneliti
menggunakan model Order of
Signifacation milik Roland
Barthes untuk menganalisa
negosiasi dan gagasan makna
interaktif antara pembaca dengan
teks yang berupa iklan.

- Level pertama (denotasi)

Pada level ini tanda dimaknai sebagaimana adanya. Barthes menyebut denotasi sebagai makna paling nyata dari tanda. Makna denotasi bersifat langsung, yaitu makna khusus yang terdapat dalam sebuah tanda, pada intinya dapat disebut sebagai gambaran sebuah petanda.

- Level kedua (konotasi)

Pada analisis kedua konotasi, tanda dimaknai menurut makna tambahannya. Konotasi

menggambarkan

interaksi yang berlangsung pada saat tanda bertemu dengan emosi dari penggunanya dan nilai-nilai kulturalnya.

- Level ketiga (mitos)

Ketika tanda lebih mengandung makna cultural daripada makna representasional, maka proses signifikasi terhadap tanda melangkah pada level mitos. Secara umum, mitos adalah cerita yang digunakan oleh suatu kebudayaan untuk menjelaskan atau memahami beberapa aspek realitas atau gejala alam. Bila konotasi merupakan pemaknaan tatanan kedua dari petanda, maka mitos adalah suatu wahana dimana ideologi berwujud. Ideologi menunjuk pada realita dimana individu maupun kelompok, secara obyektif maupun subyektif mengorientasikannya dalam dunia mereka masing-masing.

Di dalam penelitian ini, tatana pertandaan yang digunakan hanya sampai level konotasi. Tanda-tanda pada teks iklan akan dimaknai secara denotasi dan konotasi

\section{PEMBAHASAN}

Sejarah Singkat PT. HM. Sampoerna

- Generasi pertama

PT. Hanjaya Mandala Sampoerna (PT. HM. Sampoerna) adalah perusahaan rokok yang berawal dari perusahaan kecil yang 
Jurnal LINIMASA, Volume 1 Nomor 2, Juli 2018, hlm 52 - 67

didirikan pada tahun

1913 oleh Liem Sie

Tee, seorang warga

Negara cina yang

bermigrasi ke

Indonesia. Usaha

keluarga ini dibadan

hukumkan dengan

nama PT. Handel

Maatschappij

Sampoerna. Liem Sie

Tee memulai usaha

rokok dengan

memproduksi dan

menjual rokok

lintingan tangan

dengan menyisipkan

tembakau dan cengkeh

di tiap lintingannya

yang membuatnya

berbeda, bermutu dan

memiliki keajegan

dibanding produsen

rokok lain. Rokok-

rokok kretek dijual

secara komerrsial dan

diberi nama " 234 " atau

"Dji Sam Soe" dan dengan cepat menjadi popular. Rahasia kesuksesan pertama Dji Sam Soe adalah positioning yang kokoh sebagai rokok kretek premium pertama dengan cita rasa dan aroma.

- Generasi kedua

Pecahnya perang dunia II dan perjuangan untuk merebut kemerdekaan meluluhlantakkan sebagian besar negeri ini dan hampir mematikan sebagian perusahaan besar negeri ini termasuk PT HM. Sampoerna. Namun pada tahun 1965 mereka bangkit dan tetap fokus pada sigaret kretek tangan (SKT) dibawah kepemimpinan Aga Sampoerna atau Liem Swee Ling. Pada 16 juni 1968 diluncurkan merek SKT

Sampoerna Hijau untuk menegaskan kehadiran generasi kedua Sampoerna. Hal ini jelas dengan dipasangnya logo "A" yang merupkan inisial Aga Sampoerna pada kemasan Sampoerna Hijau.

- Generasi ketiga

Kepemimpinan

Sampoerna pada generasi ketiga dipegang oleh Putera Sampoerna. Masa ini menjadi penting dalam sejarah Sampoerna karena pada 1968 diluncurkanlah produk A Mild. Selain sebagai pengawal tren perokok yang peduli kesehatan, peluncuran A Mild juga menjadi bukti bahwa Putera Sampoerna berniat menjadikan

Sampoerna berbeda dan memiliki bargaining lebih dalam percaturan pasar rokok Indonesia 
- Generasi keempat

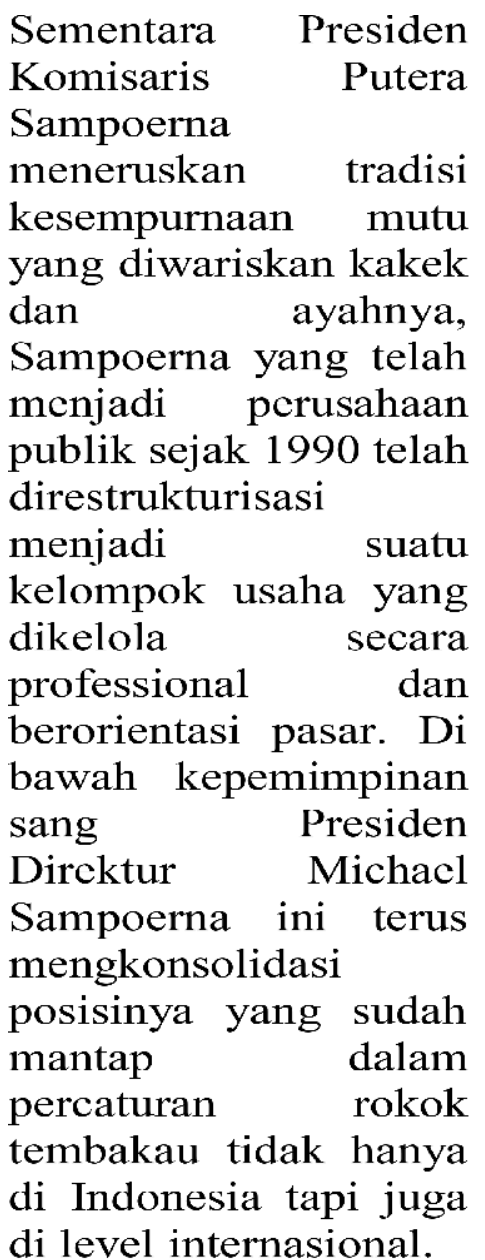

Pada tahun 1989 mendirikan PT. Sampoerna

Advertising

Nusantara, perusahaan periklanan yang melayani kebutuhan periklanan baik bagi Sampoerna mapun perusahaan lain. Mengambil peluang bisnis telekomunikasi di Singapura dengan membeli $66 \%$ saham transmarco, Minimarket Alfa, PT. Sampocrna Printpack, property mewah PT. Taman dayu Surabaya, bisnis telekomunikasi

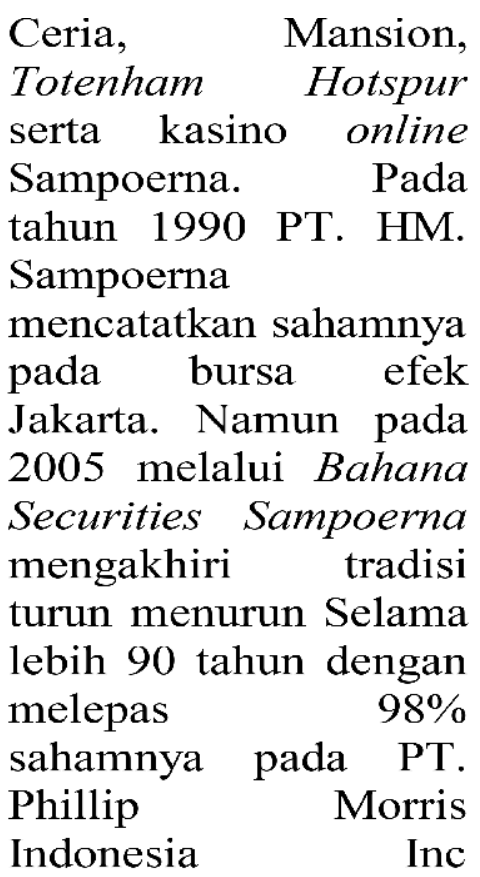
perusahaan tembakau internasional yang merupakan bagian dari PT. Altria Group Inc.

PT. HM. Sampoerna merupakan

perusahaan rokok pertama yang mendobrak pasar rokok Indonesia dengan memperkenalkan rokok kretek low tar low nicotine $\mathrm{di}$ Indonesia dalam produk andalan A Mild dan telah menjadi segmen pasar paling berkembang. Produk andalan lainnya adalah Dji Sam Soe merek lama yang mampu bertahan sejak awal masa perusahaan tersebut berdiri, serta Sampoerna Hijau yang mampu bersaing di kelas segmen menengah. 
Jurnal LINIMASA, Volume 1 Nomor 2, Juli 2018, hlm 52 - 67

\section{Produk rokok A-Mild}

A Mild adalah salah satu merek rokok andalan PT. HM. Sampoerna yang termasuk dalam kategori rokok SKM-LTLN ( Sigaret Kretek Low Tar low Nicotine). Hal ini berarti A Mild merupakan rokok yang diproduksi menggunakan mesin dengan bahan baku campuran antara tembakau dan cengkeh dan memiliki kandungan tar dan nikotin yang lebih rendah.

Kelahiran A Mild adalah wujud bagaimana Sampoerna siap bersaing di masa depan karena tren baru pada pasar rokok global. Di dunia internasional, kesehatan menjadi isu penting sehingga masyarakat membutuhkan rokok yang masih dapat menjaga derajat kesehatan mereka. Kondisi ini membuka peluang bagi rokok kategori LTLN. A Mild pertama kali diproduksi pada 1989 dengan kandungan $14 \mathrm{mg}$ tar dan 0,1 nikotin per pak nya yang menjadikannya pioneer rokok LTLN di Indonesia. A Mild juga merupakan rokok pertama yang mendobrak pasar Indonesia dengan penampilannya yang unik yaitu dengan ukuran keliling rokok $22 \mathrm{~mm}$ dan panjang rokok $90 \mathrm{~mm}$.

Kesuksesan A Mild bukan tanpa resiko. Hal ini terbukti dari keberanian Presiden Komisaris saat itu Putera Sampoerna untuk memvakumkan

Sampoerna

Exclusive untuk focus pada produksi A Mild. Langkah berani ini dinilai sangat beresiko mengingat fakta bahwa Sampoerna Exclusive telah mencapai angka produksi 90 juta batang perminggu pada saat itu. Tantangan lainnya adalah tanggapan konsumen yang masih rendah pada keberadaan rokok LTLN yang masih baru.

Namun A Mild mampu mencuri perhatian masyarakat dengan kampanye iklan yang berani dan modern dengan mengusung positioning statement ' Taste of The Future' yang berusaha mengedukasi keunggulan rokok LTLN yang berlangsung selama 5 tahun. Pada tahun 1994 A Mild merubah tema kampanye menjadi How Low you Can Go? Kemudian berkembang menjadi Bukan Basa Basi, Tanya Kenapa, Your Life Your Choice dan Go Ahead yang mampu mengedukasi masyarakat dengan bahasa yang lebih mudah dimengerti. Sejak saat itu A Mild berhasil menjadi trendsetter dan market leader di segmennya bahkan mampu meraih beberapa penghargaan, yaitu :

1. Indonesia best brand award from SWA and MARS 2002

2. Indonesia best brand award from SWA and MARS 2003

3. Indonesia best brand award from SWA and MARS 2004

4. Indonesia Costumer Loyalti Award SWA and MARS 2005

Selain itu, pada tahun 2007 A Mild dinobatkan sebagai rokok yang memiliki Top Brand Index 
(TBI) yang tinggi, yaitu 69,92 kategori rokok mild.

Kampanye iklan rokok A Mild, Brand Image \& Fenomena Sosial

Sampoerna mencanangkan
beberapa tema kampanye,
diantaranya Taste Of The Future,
How Low You Can Go, Bukan
Basa-Basi, Others Can Only
Follow, Go With The Real Low
dan Go A Head. Iklan-iklan A
Mild dikenal unik dengan bahasa
yang membumi, gampang
dimengerti dan dapat membuat
konsumen berpikir lagi terhadap
produk-produk sejenis lainnya
yang selama ini mereka kenal dan
gunakan.

\section{Positioning statement}

Taste of the future bertujuan untuk mengenalkan rokok jenis baru, yakni LTIN (low tar low nicotin) kepada masyarakat. Sebuah pesan sederhana yang menggambarkan seperti apa rasa rokok dimasa yang akan datang. Kebutuhan untuk terus membentuk citra akan rokok dan menjaga derajat kesehatan masyarakat mendorong Sampoerna melncurkan positioning statement yang baru yaitu How Low Can You Go?

Tema kampanye How low Can You Go? Menunjukkan betapa A Mild mencoba untuk mengajak konsumen melakukan re-evaluasi terhadap keberadaan berbagai merek rokok yang ada saat itu. Konsumen diajak memikirkan ulang berbagai kebiasaan dan persepsi mereka selama ini tentang rokok. Simbol re-evaluasi inilah yang membuat penjualan A Mild di tahun 1994 meningkat tiga kali lipat, dari 18 juta batang per bulan menjadi 54 juta batang perbulan. Disadari atau tidak, A Mild membentuk brand personality yang kreatif, trendsetter, cerdas dan tidak mudah diterka yang artinya $\mathrm{A}$ Mild mensejajarkan diri sebagai representasi pribadi-pribadi perokok dengan personality tersebut.

Setelah berhasil selama dua tahun dengan kampanye How Low You Can Go? A Mild meluncurkan thematic campaign baru Bukan Basa Basi (BBB). Peluncuran konsep BBB ini diawali dengan menampilkan visualisasi iklan dalam bentuk animasi gigi gigi yang menggerutu. Animasi tertsebut tentunya cukup mudah dicerna sebagai wujud representasi Buka Basa Basi.

Keberhasilan kampanye BBB dilanjutkan dengan tema kampanye Tanya Kenapa? Disini, Sampoerna berusaha untuk merepresentasikan citra konsumennya yang kreatif, trendsetter, cerdas dan kritis.

Keberhasilan A Mild di
kategori LTLN memancing
pemain-pemain baru. Akhirnya
beberapa pemain baru masuk dan
berusaha menggoyang kedudukan
A Mild. Untuk mengatasi hal ini,
A Mild meluncurkan satu tema
kampanye baru, yaitu Others Can
Only Follow. Melalui thematic
campaign ini A Mild berusaha
menyatakan bahwa pihaknya
tidak merasa terpancing akan
adanya pesaing baru, melainkan
justru melakukan manuver dan


Jurnal LINIMASA, Volume 1 Nomor 2, Juli 2018, hlm 52 - 67

menyatakan bahwa pesaing tersebut hanyalah sebagai follower.

Go With The Real Low adalah thematic campaign selanjutnya yang berusaha menyampaikan ide bahwa A Mild merupakan market leader di industri rokok LTLN. A Mild juga mengukuhkan diri bahwa iklan-iklannya dapat menjadi word of mouth yakni selalu menjadi perbincangan dan menjadi bahan diskusi banyak orang.

\section{Iklan A Mild dan Brand Image}

Berikut ini adalah iklan-iklan yang pernah diluncurkan oleh $\mathrm{A}$ Mild, dimana iklan-iklan tersebut berbicara tentang fenomena sosial yang sedang terjadi dalam masyarakat pada masanya.

A. Periode tahun 1998-1999: bertepatan dengan reformasi yang mulai digulirkan, iklan A Mild muncul dengan kalimat-kalimat yang menantang : Silahkan Blakblakan, waktunya unjuk gigi. Iklan-iklan ini adalah bagian dari thematic campaign How Low Can You Go?

Gambar 1 : Iklan A Mild, thematic campaign How Low
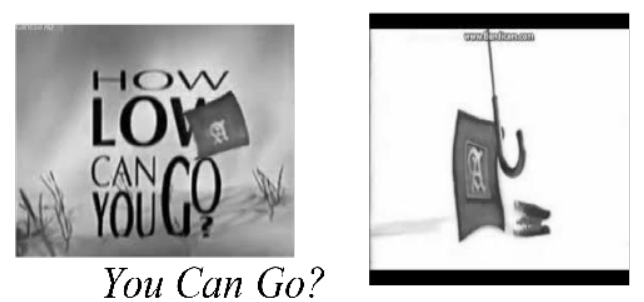

B. Periode tahun 2000-2001 : A Mild dengan tagline Others Can Only Follow merupakan sindiran terhadap produsen rokok lain yang meluncurkan produk pada kelas yang sama.

Gambar 2 : Iklan A Mild, temathic campaign Others Can Only Follow \& Go With The Real Low

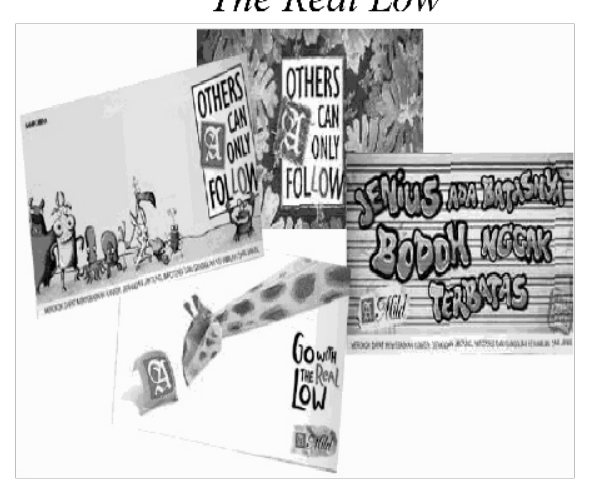

C. Periode tahun 2002 : Pada tahun ini A Mild mulai menggunakan thematic campaign Bukan Basa Basi (BBB) dengan tujuan pencitraan diri sebagai creator yang cerdas dan trend setter di kelasnya. Versi-versi iklan dengan thematic campaign BBB antara lain Daripada Curang Mending Ganti Peraturannya, Teman Sejati Bisa Berbagi Emang Pacar Bisa Dibagi?

Gambar 3 : Iklan A Mild, thematic campaign Bukan Basa Basi
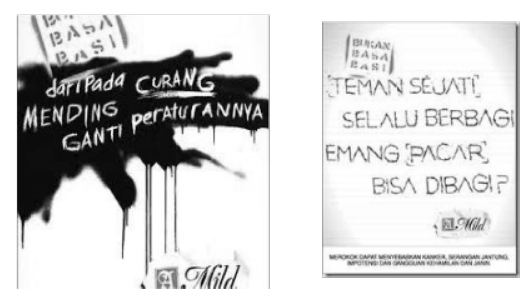
D. Periode tahun 2004 : Masih dengan thematic campaign $\mathrm{BBB}, \mathrm{A}$ Mild mengeluarkan iklan-iklan yang mencoba merepresentasikan pemilu 2004, yaitu versi Kalau Benda Bisa Ngomong, Kalo Ga Dibersihin Kutu Busuknya Ga Bakalan Pergi, serta Jangan Cuma Bisa Manas-manasin Doang.

Gambar 4 : Iklan A Mild, thematic campaign Bukan Basa Basi
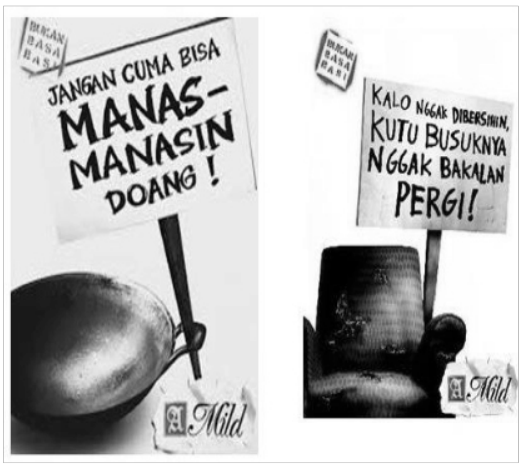

E. Periode tahun 2005-2008 : Pada tahun inilah iklan A Mild mulai menggunakan thematic campaign Tanya Kenapa yang berusaha mengajak masyarakat Indonesia untuk lebih kritis dengan selalu mempertanyakan segala hal yang sedang terjadi di sckitarnya. Versi-versi yang diluncurkan antara lain : Mau Pintar Kok Mahal, main Hakim Sendiri, Harusnya Gampang Dibikin Susah, Banjir Bandang, Taat Cuma Kalo ada yang Ngeliat. Yang Muda yang $\mathrm{Ga}$ dipercaya, Masih Banyak Celah Kok
Nyerah, Mending Ga Punya Apa-apa daripada Punya Tapi Kenapa-Kenapa.

Gambar 5 : Iklan A Mild, thematic campaign Tanya Kenapa?

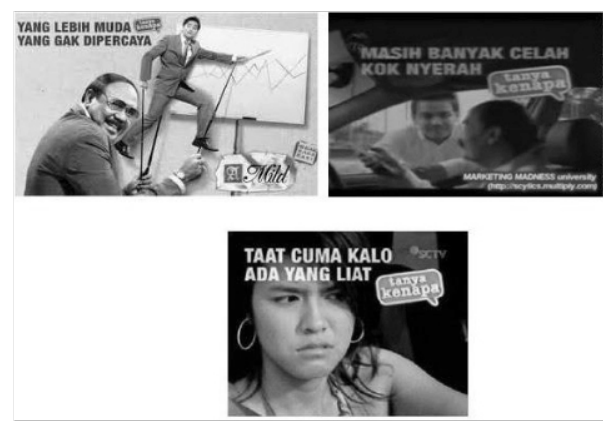

F. Periode tahun 2008-2009: Setelah booming dengan thematic campaign Tanya Kenapa, iklan A Mild mulai melakukan penetrasi pikiran dengan konsep baru Your Life Your Choice yang mencoba menjadikan konsumennya tidak hanya kritis dan cerdas namun juga mandiri atas pilihan-pilihan dalam hidup. Versi iklan dengan thematic campaign Your Life Your Choice antara lain Daripada Gak DapetDapet Kerja Mending Ga dapet-dapet Gelar serta versi Makin Banyak Pilihan Makin Bingung.

Gambar 6 : Iklan A Mild thematic campaign Your Life Your Choice Bukan Basa

Basi

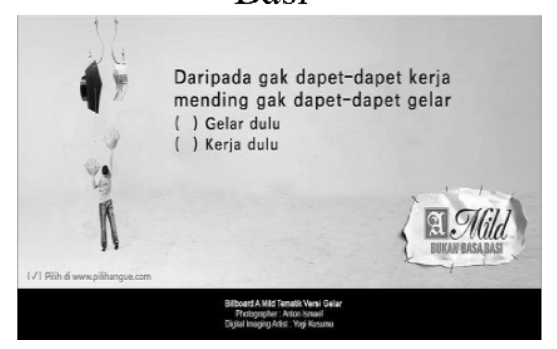


Jurnal LINIMASA, Volume 1 Nomor 2, Juli 2018, hlm 52 - 67

G. Periode 2009 - sekarang : Sepanjang tahun 2010 hingga 2017 A Mild menggunakan thematic campain Go A Head yang mencoba memberikan pesan bahwa konsumennya adalah pribadi yang berani maju tanpa takut atas resiko yang ada. Beberapa iklan dengan tagline Go A Head antara lain : Langkah (Steps), Kerja Keras, Biar Karya Bicara, Beda Persepsi, Live Your Dream, Pass it On dan lain-lain

Gambar 7 : Iklan A Mild, thematic campaign Go Ahead
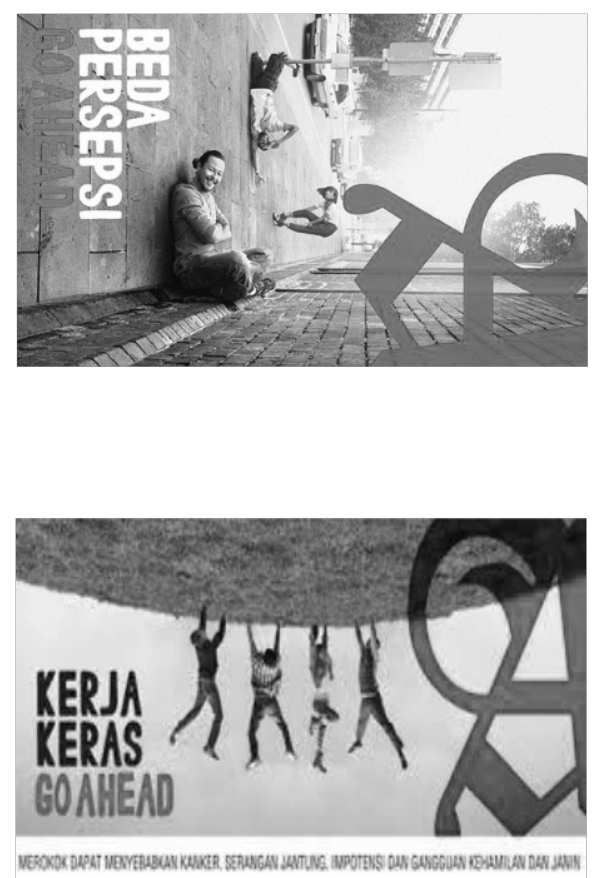

\section{KESIMPULAN}

Dari hasil penelitian yang telah dilakukan, diketahui bahwa kecenderungan iklan A Mild untuk mengangkat dan mengkritisi fenomena yang ada adalah sebuah upaya yang berkatan dengan tujuan pencitraan produk yang ingin membentuk konsumennya sebagi konsumen yang cerdas, kritis dan trendsetter dibidangnya. Hal ini adalah strategi tersendiri bagi produsen rokok A Mild yang karrena prestis yang ditanamkan dapat mempengaruhi pasar untuk dapat menjadi konsumen rokok A Mild. Dengan bahasa lain bahwa A Mild lewat iklannya ingin menyampaikan bahwa jika konsumen rokok merasa dirinya cerdas, trendsetter, up to date,berani, kritis maka konsumen tersebut pasti akan memilih A Mild sebagai rokok yang dikonsumsinya. 


\section{DAFTAR PUSTAKA}

\section{Buku}

Bulaeng, Andi. 2004. Metode Penelitian Komunikasi Kontemporer. Yogyakarta : Andi.

Dyer, Gillian. 2008. Advertising As Communication. London : Roudledge.

Effendy, Onong. 2003. Ilmu, Teori dan Filsafat Komunikasi. Bandung : PT. Citra Aditya Bakti. Elin, Larry Lapides, Alan. 2004. Designing and Producing The Television Commercial. USA : Pearson Education.

Fiske, John. 2011. Cultural and Communication Studies. Yogyakarta : Jalasutra.

Kellner, Douglas. 2005. Media Culture. New York : Routledge.

Mc.Quail, Denis. 2000. Mc.Quail's Mass Communication Theory. London : SAGE Publication Ltd.

Sobur, Alex. 2006. Analisis Teks Media. Bandung : Remaja Rosdakarya.

\section{Non Buku}

Adiwaluyo, Eko Ign. 2004. Pionir dan Jawara di Segala Lini. Majalah Marketing Edisi 09/VII.

Istanto, Freddy H. 1999. Iklan Dalam Wacana Postmodern Studi Kasus Iklan Rokok A Mild. Nirmana Journal Desain Komunikasi Visual, UK Petra.

\section{Internet}

Bohlam Advertising. 'Bedah Iklan Sampoerna' (11 Juni 2008). Diperoleh 1 Januari 2018 dari http://www.bohlamadv.blogspot.c om/2008/06/bedah-iklansampoerna.html. 